\title{
Editors' introduction: Special issue on poverty and social exclusion in Turkey
}

\author{
Fikret Adaman and Deniz Yükseker
}

Scholarly interest in poverty and its consequences has been revived in the last two decades, as international economic institutions and social scientists alike have drawn attention to its globally persistent character. In the case of Turkey, although poverty has always existed, studies on this phenomenon have flourished only in the past decade. This newfound focus on the subject comes at the conjuncture of several processes: Turkey's embarkation on economic liberalization in the early 1980 s, which then gained pace in the following decade, has had lasting impacts on the agricultural sector, the structure of urban employment, and urban housing markets. The two economic crises in 1994 and 2001 made apparent the vulnerability of workers under neoliberal economic policies. At the same time, the armed conflict between the Kurdish Workers' Party (PKK) and the Turkish army has had devastating social consequences, including the forced displacement of hundreds of thousands of Kurds from their homes.

In the meantime, some experts at the World Bank were drawing attention to the negative effects of neoliberal reforms implemented in many developing countries and calling for policy devices to build safety nets against their social ravages-in their parlance, "social risks"-while at the same time continuing to work towards reducing global poverty levels. In the European Union (EU), high unemployment rates, concerns regarding the insufficient integration of immigrants, and growing prejudices against minorities prompted policy and social science circles to focus on the need for social cohesion. Hence, EU policy emphasized the reduction of "social exclusion" with a view to increasing social integration, rather than simply alleviating poverty.

Following Turkey's candidature for accession to the EU in 1999, the coincident onset of a period of relative calm in the armed conflict, and the 2001 financial crisis, social science and policy discussions in Turkey thus

\footnotetext{
Fikret Adaman, Economics Department, Boğaziçi University, Bebek, istanbul, Turkey, adaman@boun.edu.tr.

Deniz Yükseker, Sociology Department, Koç University, Rumeli Feneri Yolu, Sarıyer, İstanbul, Turkey 34450,dyukseker@ku.edu.tr.
} 
came to be informed both by the World Bank's growing concern over mitigating social risks and the EU's concern over reducing social exclusion.

On a theoretical level, we observe that certain issues raised in Turkey echo elements of the heated debate about the need for social justice in the past two decades among economists, sociologists and political scientists. This period has witnessed a growing dissatisfaction with addressing issues of social justice solely in terms of economic magnitude, such as wealth and income inequality. This has led to revisions of development measures, to include health (via indices such as life expectancy at birth, infant mortality, number of patients per doctor) and education (via indices such as literacy, years of education, enrollment rate, book consumption per capita). ${ }^{1}$ Nonetheless, this broadening of perspective was insufficient in bringing about a radical change in some economists' and policy makers' perceptions of social justice. Better access to health and education services; hence, economic growth, they argued, would eventually reduce poverty, even if no attempts were undertaken to curb unequal income distribution. ${ }^{2}$

Criticism against reducing issues of social justice merely to income redistribution, economic growth and poverty alleviation began to be voiced more loudly at the beginning of the 1990s. The main point was that, although they were willing to, some individuals/families/groups were fully or partially unable to participate in certain fields of social life due to reasons other than economic ones. Accordingly, certain people are pushed out of social life because of processes that are non-economic or cannot be reduced to economic reasons-thus, more emphasis was put on the term "social exclusion."

One can define social exclusion concisely as a process whereby individuals and groups are pushed to the edge of society and prevented from participating fully in social life, by virtue of their poverty, their lack of basic competencies and lifelong learning opportunities, or as a result of discrimination. Hence, social exclusion is a multidimensional concept, including not only income deprivation, but also cultural, political and spatial processes; it may also be a self-perpetuating process.

Focusing on Turkey, a broad consensus in the literature reveals thatalthough the most important reason for social exclusion is poverty, leading

1 For a review of the evolution of different definitions of development, see, Charles Gore, "The Rise and Fall of the Washington Consensus as a Paradigm for Developing Countries," World Development 28, no. $5(2000)$.

2 For critical perspectives on this argument, see, Ravi Kanbur, "Economic Policy, Distribution and Poverty: The Nature of Disagreements," World Development 29, no. 6 (2001), Robert Hunter Wade, "Making the World Development Report 2000: Attacking Poverty," World Development 29, no. 8 (2001). 
to the necessity to focus on the political economy of production, as well as on distribution and re-distribution processes-there exist cultural, spatial and political dimensions of social exclusion, and several forms of discrimination may be experienced due to insufficient citizenship rights, the prevalence of social prejudices, and the inadequacy or lack of certain social services. ${ }^{3}$

Despite the fact that Turkey has achieved relatively high growth rates in the last few years, per capita income is still very low when compared to EU levels. Coupled with a much skewed income distribution, this leads to a significant incidence of poverty. Indeed, even though the population falling under the "food poverty" line (a line demarcating those having just enough to survive physically) is insignificant, the picture dramatically changes when one considers the "risk-of-poverty" rate (defined as 60 percent of the median of equivalized net income of all households). ${ }^{4}$ The geographical unevenness of income distribution makes the picture even more disturbing, as the average per capita income in the eastern and southeastern provinces is less than half of that in the western provinces. This unevenness is clearly visible in indices of human development, such as life expectancy figures, with an eight-year difference between the eastern and southeastern regions and the west. ${ }^{5} \mathrm{~A}$ further dichotomy is between the rural and the urban areas of Turkey; the fact that those living in rural areas, comprising about onethird of the population, contribute only about one-sixth of the GDP indicates the extent of the income differential between the two. ${ }^{6}$

The principal determinant behind poverty is the high rate of unemployment, which has persisted during the last decade and shows no signs of decreasing in the near future. The economic growth that the country has enjoyed in recent years has shown only an insignificant positive effect on employment. Furthermore, the large volume of the informal sector in the country's economy-conservative figures put it at around 30 percent of the total non-agricultural employment-implies that a significant number of the employed live without job security and social insurance. $^{7}$

3 For a thorough discussion of these points, see, Fikret Adaman and Çağlar Keyder, eds., Poverty and Social Exclusion in the Slum Areas of Large Cities in Turkey, Report for the European Commission, Employment, Social Affairs and Equal Opportunities (Brussels: Report for the European Commission, 2006).

4 See, for example, Turkey and World Bank State Institute of Statistics, Joint Poverty Assessment Report, vol. 1 (2004).

5 For human development and poverty indicators for eastern and southeastern regions of Turkey, see, TESEV Doğu ve Güneydoğu Anadolu'da Sospal ve Ekonomik Oncelikler (istanbul: TESEV, 2006).

6 State Planning Organization Social and Economic Indicators (Ankara: DPT, 2008).

7 Maliye Bakanlığı Hesap Uzmanları Kurulu "Türkiye'de Kayıt Dışı Ekonominin Boyutu," (Ankara: T.C. Maliye Bakanlı̈́(, 2005). 
If properly designed, social services can potentially counterbalance these problems. In the case of Turkey, however, social programs are under-funded, suffer from administrative and organizational problems (which translate to efficiency losses), and fall short of meeting equitability criteria. Education, health and pension schemes currently provide low-quality and inadequate services, except to the privileged few at the top of the income and status scale. Furthermore, specifically designed schemes aimed at alleviating poverty fall short of meeting their targets. The picture is even grimmer when we consider that traditional mechanisms of cooperation and insurance against risks—such as family and other social networks-are also eroding. 8

Since a significant portion of the society are either unemployed or employed in the informal sector, without social security or health insurance and facing deteriorating social safety, we can conclude that there potentially is a high incidence of social exclusion. Although local governments and civil society initiatives have made some contributions in the fields of healthcare and education, and although there are several new social assistance projects designed to alleviate aspects of exclusion (such as the conditional cash transfer program for families with school children, or the "green card" free healthcare program for the poor), it is obvious that long-term structural interventions are necessary to prevent the deepening of social exclusion.

The contributions to this Special Issue on Poverty and Social Exclusion in Turkey reflect the fruits of an ongoing and critical engagement with the international debates on poverty and social exclusion, both among scholars and policy-makers, as we outlined it above in light of the Turkish experience. Each article approaches a particular aspect of the problématique, consisting of poverty and social exclusion, as well as of the historical and current evolution of relevant social policies. Furthermore, some of the essays suggest new avenues for research concerning these issues.

First of all, this Special Issue of New Perspectives on Turkey seeks to demonstrate the incidence and characteristics of social exclusion, without claiming to cover all aspects of it. Fikret Adaman and Oya Pınar Ardıç's contribution, "Social Exclusion in the Slum Areas of Large Cities in Turkey," focuses on the different forms of exclusion experienced in innercity and gecekondu areas in six metropolitan cities in Turkey, based on the results of a large-scale survey. The evidence from the survey suggests that a significant proportion of people living in these areas are distanced from jobs, income, education and training opportunities, with little access to

8 Ayşe Buğra and Çağlar Keyder, New Poverty and the Changing Welfare Regime in Turkey (Ankara: UNDP, 2003). 
power and decision-making bodies; this inevitably pushes them to the edge of sociery. The study also reveals that, in addition to economic problems, there exists a combination of cultural and social constraints on residents of slum neighborhoods.

Other contributions also shed light on the incidence and characteristics of social exclusion in Turkey. Particularly Işı Aytaç and Bruce Rankin's study, "Unemployment, Economic Strain and Family Distress: The Impact of the 2001 Economic Crisis," presents strong evidence regarding the vulnerability of poorer segments of the population in the face of sudden economic downturns. They discuss economic hardship in the wake of the 2001 economic crisis and the impact of the resulting economic strain on individuals and family life, based on a nationally representative sample of urban households. Analysis of the survey results show that those who lost their jobs had a longer duration of unemployment, experienced higher levels of economic strain, and were affected most by the crisis. Their evidence furthermore indicates that economic strain also negatively influences stress levels, and family and marital relations. Several other essays in this issue also discuss the characteristics of exclusion-such as its multiple dimensions, its particular effects on women and Kurdish migrants, and the impact of government policies on reproducing exclusion.

As we mentioned above, several schemes for alleviating poverty and reducing exclusion have been put into place in the past years. But are the diagnoses of problems and policy recommendations suggested by international bodies and implemented by Turkish governments adequate? In "Missing Links in Poverty Analysis in the Age of Neoliberal Globalization: Some Lessons from Turkey," Fikret Şenses is critical of international financial institutions' explanations of the reasons for poverty under the purview of neoliberalism, as well as their suggested solutions. On the contrary, he argues, neoliberalism breeds poverty; therefore, neoliberal poverty alleviation policies are not particularly effective. Ayşe Buğra and Sinem Adar's essay, "Social Policy Change in Countries without Mature Welfare States: The Case of Turkey," provides further support for this argument. They observe that, contrary to expectations, neither in developed countries nor in countries without mature welfare states such as Turkey, social spending has significantly decreased under neoliberalism. In the Turkish case, the increase in social assistance stems rather from a concern with halting social disintegration in the face of liberal economic reforms; however, it is not based on a notion of social citizenship rights for the excluded. They further argue that the increasing emphasis on non-state actors in dispensing social aid in Turkey is in line with characteristics of welfare governance currently promoted at the international level. 
When viewed from a historical perspective, the Turkish state has never been a dominant actor in the field of welfare provision, charity and social assistance, ${ }^{9}$ while families have always been at the center stage. ${ }^{10}$ The present government's controversial proposal for the reform of the social security system is a test case for whether this built-in familial ideology will be weakened. In fact, a familial and paternalist ideology was always present in the development of Turkish social policy-a case in point being social policies towards women. Azer Kılḩ̧, in "Continuity and Change in Social Policy Approaches toward Women," discusses the evolution of social policy in Turkey from a gender perspective, from the Ottoman era to the present. She suggests that, while with the introduction of the modern social security system in the post-World War Il period women were increasingly integrated into the system either as workers or as dependents of workers, assumptions about women's place both in the family and the labor market did not change much. Kılıç argues that familial dependency and traditional gender norms have been reinforced through genderdifferentiated policies. Although, as she observes, social policies have been moving towards equal treatment of men and women during the past two decades, one of the points in the current debate surrounding the ongoing reform of the social security system is that women are being relegated to a secondary and dependent status in a manner that penalizes their labor force participation.

The familial ideology intrinsic in state policies and its contribution to the social exclusion of women and children come into sharper view in Berna Yazıci's essay on "Social Work and Social Exclusion in Turkey: An Overview." Focusing on the contemporary reform of the child protection system, she shows its link with the neoliberal agenda of reducing state social spending and shifting social care from state to familial resources. This perpetuates the exclusion of women and children who are the major clients of the social work system. At the same time, however, other features of the existing social work system-such as the society centers-help remedy some aspects of the social exclusion of women and children.

As much of the scholarship on social exclusion emphasizes, processes of social exclusion often stem from the malfunctioning of institutions that should have ensured social cohesion in the first place. ${ }^{11}$ State policies and agencies are obvious targets of criticism in this sense. In different ways,

9 Ayşe Bugrra, "Poverty and Citizenship: An Overview of the Social-Policy Environment in Republican Turkey," International Journal of Middle East Studies 39, no. 1 (2007).

10 Buğra and Keyder, New Poverty and the Changing Welfare Regime.

11 See, for instance, Ajit S. Bhalla and Frédéric Lapeyre, Poverty and Exclusion in a Clobal World (London: Macmillan Press, 1999). 
Şenses, Buğra and Adar, and Yazıcı all touch upon the role of the state in the failure to alleviate poverty and social exclusion, while at the same time they point towards ways in which more cohesive economic and social policies can be developed. In fact, the state plays a fundamental role in reproducing social exclusion, not only through social policy, but also through its redistributive mechanisms.

The taxation system, which collects a share of the income generated in the country and then redistributes it in the form of public and social services, in fact regenerates social inequalities. This is what Fatoş Gökşen, Gökhan Özertan, İsmail Sağlam and Ünal Zenginobuz argue in their contribution, entitled "Impacts of the Tax System on Poverty and Social Exclusion: A Case Study on Turkey." Their quantitative analysis of the Turkish Household Consumption Survey reveals that regressive consumption taxes result in the poor paying a disproportionate amount of their income as indirect taxes, more so for those in Eastern and Southeastern Anatolia where poverty is more extreme. Their qualitative analysis of interviews with various stakeholders shows that different citizen groups consider the current tax system to be highly unfair and feel that they receive very little in terms of public services in return for the taxes they pay. Another finding is that many citizens are reluctant to pay taxes, thus protesting the degradation of public services, unfairness, corruption, and other administrative failings.

As we mentioned at the outset, one of the reasons behind the exacerbation of poverty in Turkey in the past two decades has been the armed conflict in the eastern and southeastern regions. On the one hand, the conflict devastated the livelihood of both the rural and urban economy in the region. On the other hand, it led to the forcible displacement of nearly a million people, primarily from their rural homes, either towards urban centers in the region or metropolises in Southern and Western Turkey. Processes of social exclusion were intensified both as a direct result of the conflict and through the forced migration of people to cities-for which the state was principally responsible-where they had little access to employment, education, healthcare, and political representation. ${ }^{12}$

Bediz Yllmaz's essay, "Entrapped in Multidimensional Exclusion: The Perpetuation of Poverty among Conflict-Induced Migrants in an İstanbul Neighborhood," examines the reproduction of the social exclusion of displaced Kurds who have settled in the inner-city neighborhood of

12 On the state's role in internal displacement, see, Bilgin Ayata and Deniz Yükseker, "A Belated Awakening: National and International Responses to the Internal Displacement of Kurds in Turkey," New Perspectives on Turkey, no. 32 (2005). 
Tarlabaşı in İstanbul. Her ethnographic evidence clearly demonstrates that the majority of the residents there have little access to regular jobs; that the incidence of child labor is high; and that society at large attaches a stigma to being Kurdish in Tarlabaşı. The social, economic, political, discursive and spatial dimensions of social exclusion in this neighborhood prevent social integration. Her case study also gives a vivid example of the interwoven and mutually reinforcing nature of various dimensions of exclusion.

As several of the authors in this Special Issue argue, some of the poverty alleviation mechanisms promoted by international financial organizations are not entirely adequate to achieve their stated goals, because they leave intact the existing unequal distribution of wealth and economic resources. One such policy device which has been praised by many in the international policy-making and academic communities is the microcredit program developed three decades ago by the Bangladeshi economist Muhammad Yunus. However, its critics argue that the microcredit program draws its impoverished participants into market processes and even capitalizes on their poverty through market-rate interests on the loans, rather than removing their poverty. ${ }^{13}$ Tuğçe Bulut's ethnographic study on the implementation of the microcredit project in Diyarbakır, the largest and one of the poorest cities in the Southeast, draws a different picture of this microcredit program. In "Community Matters: A Study of the Interaction of Microcredit Borrowers in Diyarbakır with the Market Economy," Bulut agrees with the argument that microcredit programs. facilitate the integration of borrowers into market mechanisms. But she contends that the borrowers adjust the microfinance system to suit their own needs and that they embed it within local solidarity networks.

The various essays in this issue highlight important aspects of the problem of poverty and social exclusion in Turkey. These range from critiques of neoliberal reforms propagated by international institutions and implemented by governments to quantitative and qualitative descriptions of the various facets of social exclusion, from the impact of taxation to the effects of social work and social security policies. Although the ground covered by these studies is not exhaustive, we hope that the bringing together of various perspectives and methodologies will open up new vistas for scholarly and policy-oriented research which will contribute to the fight against poverty and social exclusion in Turkey.

13 See for example, Ayşe Buğra, "Yoksullukla Mücadele Yöntemi Olarak Mikrokredi: Acıklı Bir Hikaye," Sosyal Politika Forumu Bülteni, no. 2 (2007), Alexander Cockburn, "The Myth of Microloans," The Nation, 6 November 2006. 


\section{Bibliography}

Adaman, Fikret, and Çağlar Keyder, eds. Poverty and Social Exclusion in the Slum Areas of Large Cities in Turkey, Report for the European Commission, Employment, Social Affairs and Equal Opportunities. Brussels: Report for the European Commission, 2006.

Ayata, Bilgin, and Deniz Yükseker. "A Belated Awakening: National and International Responses to the Internal Displacement of Kurds in Turkey." New Perspectives on Turkey, no. 32 (2005): 5-42.

Bhalla, Ajit S., and Frédéric Lapeyre. Poverty and Exclusion in a Global World. London: Macmillan Press, 1999.

Buğra, Ayşe. "Poverty and Citizenship: An Overview of the Social-Policy Environment in Republican Turkey." International Journal of Middle East Studies 39, no. 1 (2007): 33-52.

"Yoksullukla Mücadele Yöntemi Olarak Mikrokredi: Acıklı Bir Hikaye." Sosyal Politika Forumu Bülteni, no. 2 (2007): 1.4.

Buğra, Ayşe, and Çağlar Keyder. New Poverty and the Changing Welfare Regime in Turkey. Ankara: UNDP, 2003.

Cockburn, Alexander. "The Myth of Microloans." The Nation, 6 November 2006.

Gore, Charles. "The Rise and Fall of the Washington Consensus as a Paradigm for Developing Countries." World Development 28, no. 5 (2000): 789-804.

Kanbur, Ravi. "Economic Policy, Distribution and Poverty: The Nature of Disagreements." World Development 29, no. 6 (2001): 1083-1094.

Maliye Bakanlı̌̆ı Hesap Uzmanları Kurulu “Türkiye'de Kayıt Dışı Ekonominin Boyutu.” Ankara: T.C. Maliye Bakanlı̆̆ı, 2005.

State Institute of Statistics, Turkey and World Bank Joint Poverty Assessment Report. Vol. 1, 2004.

State Planning Organization Social and Economic Indicators. Ankara: DPT, 2008.

TESEV Doğu ve Cüneydoğu Anadolu'da Sosyal ve Ekonomik Öncelikler. İstanbul: TESEV, 2006.

Wade, Robert Hunter. "Making the World Development Report 2000: Attacking Poverty." World Development 29, no. 8 (2001): 1435-1441. 